\title{
Review
}

\section{Among the New Books}

\section{ANTHONY SINCLAIR}

$\Longrightarrow$ Snatching corpses, illegal dissection, the secret burial of body parts in (dank?) cellars and the haunting figure of 'The Resurrection Man' are all to be found in ROBERT L. BLAKELY \& JUDITH M. HARRINGTON's (ed.) Bones in the basement: postmortem racism in nineteenth century medical training ( $\mathrm{xix}+380$ pages, 50 illustrations. 1998. Washington (DC) \& London: Smithsonian Institution Press; 1-56098-750-2 hardback $\$ £ 34.95$ ), an, almost, Gothic horror story for (osteo-)archaeologists. The truth, however, is possibly less entertaining. In turning the old Medical College in Augusta, Georgia — a greek-revivalist 'temple'-like building, and now a national monument - into a museum, workers brought pits of human and animal bones to the surface. Salvage archaeologists then recovered some 9800 human bones and 2000 artefacts, including old syringes, pipettes and scalpels. Osteoarchaeological studies of the bones suggest that most of those dissected were black males, whilst patterns of dissection were much like today's, except that many of the bones showed signs of postmortem amputation, suggesting the practice of common (at the time) surgical techniques by trainee doctors. Ironically, whilst dissection was as important to medical training in the first half of the 19th century as it is today, it was also illegal. Corpses were, therefore, not donated for dissection. Some were 'provided' by people who came for their free, but experimental, treatment at the College; others came more surreptitiously. The members of the faculty of the Medical School, purchased a slave, Grandison Harrison, whose job it was to acquire bodies for them. He did this by frequenting alleyways in search of the dead and dying poor, and by grave-robbing from Cedar-Grove cemetery, the burial place of Augusta's black community and indigent population. Creeping into the cemetery late at night, Harrison quickly dug down to the upper end of the coffin and pulled out the body with his allegedly powerful arms. To be black, a slave or pauper in Augusta meant that your 'call' to the surface might be from Grandison Harrison, 'The Resurrection Man'. For his efforts he received a salary, room, board and plenty of liquor - the corpses were also preserved in vats of whisky. It would be easy to present Harrison as a sort of Hammer Horror bogey-man, lurking in the Augustan shadows and the medical faculty pho- tos; but he was a more complex figure. In the black community, he cut a certain dash, a man deserving of respect and fear; in the Medical College, he did not just provide the bodies, he was also the man the (white) students turned to more easily for anatomical advice in dissection classes, such were his corporeal skills. Today in Augusta, black students also learn the skills of medicine, and bodies are donated to the medical schools. They are almost all white.

$\Rightarrow$ Thinking of exploration in the 15th century brings images of Christopher Columbus to mind. Just as important, however, were the explorations of Portuguese sailors such as Vasco da Gama and Magellan along the western coast of Africa and into the Indian Ocean. As a result of these vogages our map of the world changed, quite literally. In JERRY BROTTON's Trading territories: mapping the early modern world (208 pages, 8 colour plates, 36 illustrations. 1997. London: Reaktion Books; 1-8618-9011-7 hardback $£ 22.50$ ) we find out how the movement of sailors into waters far offshore necessitated a radical remodelling of the maps and charts by which the world had been drawn. The mappa mundi, based on the geography of Ptolemy, gave way to maps in which Africa became a continent with the shape we know today, as Portuguese traders rounded Cape Bojador and explored the coasts of Guinea. Expansion of the known world was rapid, averaging over one degree south each year. In 1435 the tropic of Cancer was crossed, and by 1460 the Cape Verde islands were reached. In 1473 the equator was crossed and by 1488 Bartolomeu Días had rounded the Cape of Good Hope. In 1498 da Gama landed in Calicut with gifts from Manuel of Portugal to secure the trade of spices, woods and precious stones with the Samorin of Calicut. The maps that resulted were not those of colonial powers: they were not about the ownership of tracts of land, but the marking of places for trade and the routes to and fro. This graphic expansion was not all. The curvature of the earth led astray ships sailing according to the flat portolan maps of the medieval period, with their straight-line headings between ports, once they were beyond the visible confines of the Mediterranean and the islands off the northwest coast of Africa. In 1493 a cloth merchant from Nuremberg, Martin Behaim, was 
commissioned, at the cost of $£ 1317 \mathrm{~s}$, by the good burghers of that city to produce a globe on account of his voyages with the Portuguese. In the 1560s, Mercator's projection rendered the globe flat, and rolled charts once more set sailors on their way. This projection, however, was not just a feat of mathematics. Mercator's compression of the north-south axis in favour of an expanded east-west axis suited the 16th-century world and its new trading concerns oriented towards the New World and East Asia.

$\notin$ For archaeologists of prehistoric periods, the prospect of textual evidence concerning the meanings of material things, not to mention their names and uses, is a dream, whilst for those struggling with the written source's critical problems, the prospect of working in a period where such problems of meaning no longer exist seems strangely idyllic. Over the years a number of people have attempted to unravel this paradox, the latest of whom is ANDERS ANDREN in Between artifacts and texts: historical archaeology in global perspective. (Contributions to global historical archaeology. $x+215$ pages, 41 illustrations. 1998. London \& New York (NY): Plenum; 0-30645556-0 hardback \$39.50). One of the problems, suggests ANDREN, is that archaeologists of prehistoric periods realize that they are working on a common project and share debates in methodology and theory, whilst this is not the case for historical archaeologists; the disciplinary boundedness of historical archaeologies prevents scholars from seeing their problems in common. Brief reviews of historical archaeologies in northern and western Europe, the Near East and the Americas, including Japan and China, lead ANDREN to recognize five common fields of scholarship in which texts and artefacts have been brought together; aesthetics, philology, protohistory, culture history and archaeology. Despite the presence of these fields, there remains the belief among historical and prehistoric archaeologists alike that where texts abound artefacts take second place in interpretation and vice versa. What is needed is a recognition of the methodological nature of the relationship between texts and artefacts per se. ANDREN tackles precisely this point by suggesting that relationship between texts and artefacts is like that between different forms of analogies; it can take the form of correspondence, contrast and association. When texts and artefacts correspond there are points of likeness or reinforcement between them, such as in the identification of a place named in a text, or the naming of an object. This is the classic use of archaeologial evidence to illustrate texts. When they contrast they reveal the different patterns of cultural behaviour associated with both forms of evidence. For example, in Shang dynasty China, the area revealed by stylistic similarity in bronzes is much greater than that revealed by mention on oracle bones.
There are, then, cases where text and artefact are associated, such as the glyphic inscriptions of the greatness of Mayan rulers on the steps leading up to the temple tops where captives would be sacrificed. To ANDREN this is a form of rhetorical flourish. Whilst ANDREN has not defined an historical archaeology he has usefully articulated an aspect of the relationship between texts and artefacts.

Fernand Braudel noted in his essay on the longue durée that it was the sight of streams of French refugees fleeing the German armies into Vichy, France that impressed upon him the force of longer-term processes in history. It maybe a similarly sad reflection on the scale of the political realignments and unrest of Europe that brings migration and invasion back to our consciousness in theory again. JOHN CHAPMAN \& HELENA HAMEROW's (ed.) Migrations and invasions in archaeological explanation. (BAR International series 664. iii+81 pages, 20 figures. 1997. Oxford: Archaeopress; 0-86054-857-0 paperback £19) is a slim and interesting outcome from a TAG session in Durham in 1993. The essence, following some of David Anthony's comments in American Anthropologist a few years ago, is that the New Archaeology's disposal of migrations and invasions in the 1960s, though still present in David Clarke's Analytical archaeology, was close to throwing the baby out with the bathwater. Made all the more incomprehensible since it was replaced by a concentration upon population expansion and food pressures in many new explanations. Migrations and invasions have definitely existed and cannot be ignored, even if they are hard to observe archaeologically, or lie beyond the reach of our chronological resolution. As such they deserve to be investigated as one form, amongst a number, of social movement, a matter followed up by Anthony himself in this volume. In a thoughtful, historicizing paper, CHAPMAN wonders why migrations and invasions persisted longer in European archaeologies than their Anglo-American counterpart. It was, he argues, the product of the lack of experience of invasion or large-scale migration in these areas for most of the 20th century; the continued movement of armies or refugees across continental Europe has constantly kept archaeologists aware of the realities of large-scale population movement.

$\notin$ The nature of Dutch archaeology has changed dramatically since the 1980 s with the recognition of the escalating erosion of the archaeological record, amongst other things. An appreciation of these changes appears in W.J.H. WILLEMS, H. KARS \& D.P. HaLtewas' (ed.) Archaeological heritage management in the Netherlands: fifty years of state service for archaeological investigations (vi +362 pages, numerous plates \& figures. 1997. Amersfoort: ROB; 90-232-3304-2 paperback Dfl 75 \& \$37.50) which 
provides a series of articles, including considerations of nautical, aerial and urban archaeologies, as well as sceintific conservation and the holding and ownership of archaeological collections, devoted to the work of the ROB - the Dutch State Service for Archaeological Investigations. Originally set up as an excavation service and and for the purposes of maintaining a register of archaeological finds and monuments, it is now becoming a national centre for the management and research of the national heritage. Those with an interest in sites and monuments records will be interested to read how the Dutch have tackled this same problem. Archaeological atlases based on an inventory of finds and find-spots were produced by the National Museum of Antiquities from 1845. The ROB set up a new documentary system in 1950 allowing searches by location, period, technology and typology, called the Central Archaeological Archive. From 1974 with the aid of the state computer centre, the CAA could be investigated (for new finds) according to 29 criteria. By the 1980s a separate archive of information on sites that might qualify for protection under the Monuments Act of 1961 had been created, the Central Monuments Archive. Yet the data from the two archives did not match; finds and find-spots from the northern provinces had been recorded in a separate 'northern' archive. So from 1987 a new combined record was created, the Archaeological Information System - ARCHIS. ARCHIS will contain not just the information from the CAA and CMA but from many other data-bases, and the implementation of a GIS component will lead to rapid production of maps for planning purposes. From 1997 it has been possible to search ARCHIS graphically on the Internet. This is, however, not the end: a virtual archaeological archive of the Netherlands is in prospect.

$\$$ Last quarter I mentioned Paul Devereux's book The Long Trip: a prehistory of psychedelia enthusing about the range of evidence that he had marshalled to detail the use of psychedelia-inducing drugs and practices in prehistory. The final section of this book set out Devereux's theory that there was a connection between ley lines and the straight flights of shamans. Of this I was a little bit sceptical. As if by magic, along has come ALBY STONE's Straight track, crooked road: Leys, spirit paths and shamanism. $(\mathrm{v}+90$ pages, 15 jllustrations. 1998 . Loughborough: Heart of Albion Press; 1-872883508 paperback $£ 9.95$ ), which takes a longer, more detailed look at precisely this matter, and finds this new shamanic turn in ley-line studies sorely inappropriate. STONE argues that Devereux, and others who have followed his lead, have glossed over the variability in shamanism, and overplayed the evidence relating to a number of other straight-line phenomena; ghost roads and corpse tracks, the linguistic relationship between kingship, straightness and shamanism, and clear evidence of angles in other- wise straight tracks in European prehistoric monuments. Whilst there is strong relationship between shamanism and straight tracks in South America (as properly recognized by Devereux), there are no such links between straight tracks and shamanic paths in the Altaic/Uralic tradition of shamanism in Eurasia, which is more appropriate to European phenomena. Indeed, when the movements of shamans are mentioned at all, there is common reference to the winding nature of their travels. The Dutch straight corpse pathways used as corroborating evidence are inappropriate: they are all recent phenomena. Moreover, other corpse paths are markedly crooked and ambulatory. The linguistic links between words with reg- as roots and kingship and straightness in shamanism is also not that simple. STONE argues that such words are Italo-Celtic in origin; they cannot explain earlier phenomena of the Neolithic, and there is no clear relationship to shamanism at all. Finally, many of the straight monumental phenomena of the Neolithic also contain distinct and deliberate changes in direction at points on their path. These remain to be explained.

\section{Monographs}

For those who also teach a course on social anthropology, try ROBERT LAYTON's An introduction to anthropological theory $(\mathrm{xi}+241$ pages, 22 figures, 8 tables, 1998. Cambridge: Cambridge University Press; 0-521-62982-9 hardback £35, paperback £12.95). In a few short chapters LAYTON introduces readers to the main theoretical postions that have influenced anthropological writings since the time of Malinowski; functionalism, structuralism, Marxism, social interractionism, socioecology and Postmodernism. All are covered, succinctly and clearly: the discussion of Lévi-Strauss and kinship is comprehensible! Having avoided the perspective of destroying previous theories with a view to their replacement by something better, LAYTON presents a reasoned assessment of the contribution, positive and negative, of these different perspectives to anthropological debates today. His discussions of socioecology and, especially, Postmodernism, which he argues are currently the most 'productive' theories in anthropology at the moment, are excellent. For those wondering where the problems lie in reference and text in the work of Derrida, Layton suggests a re-reading of Quine and the subject of ostensive references. A table can be a table after all, and not just 'not-a-chair', 'not-a-sofa', etc. In a concise, readable book LAYTON has produced a theoretical guide that will find itself a ready audience almost immediately. This book will make a significant addition to an already full shelf of good introductory texts on anthropology, and frankly it is the text that many might crave for archaeological theory; it doesn't work too badly for that purpose either.

The relaunch of the British Archaeological Reports, under the auspices of Archaeopress in $\mathrm{Ox}$ - 


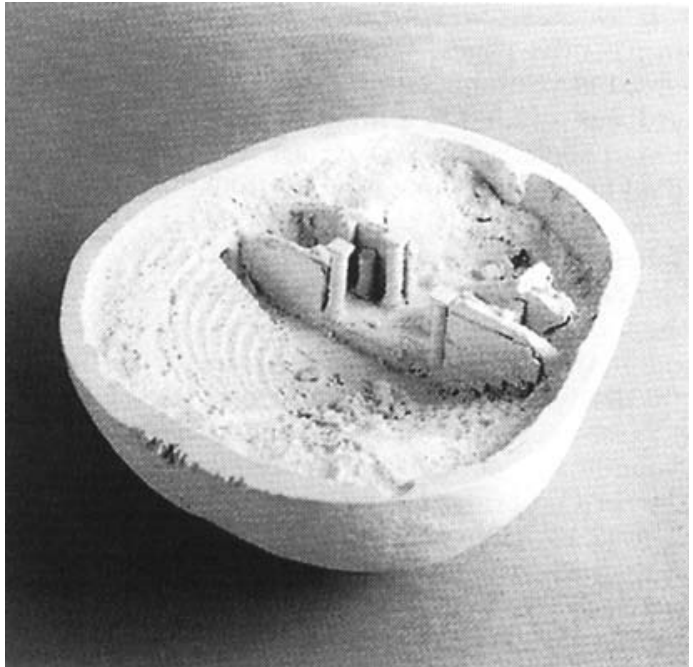

\# Memoria Mundi (No. II) by Anne \& Patrick Poirier. Gathered together in this cabinet of curiosities are the archives of the site Mnemosyne (the Greek word for memory), excavated by an archaeologist-architect; a cast taken from a bronze sculpture, a cranium containing an ancient ruined theatre, a field notebook and other artefacts. Each object suggests the evidence of a civilization, but the archive is incomplete, and the notebook contains no clue that allows any of the artefacts to be situated in place or time: a collection of fragnents, the ruins of a memory. Accompanying an exhibition at the Getty Research Institute, MICHAEL ROTH's (ed.). Irresistible decay: ruins reclaimed (xii+109 pages, 20 colour plates, 20 black \& white plates. 1998. Los Angeles (CA): Getty Research Institute; 0-89236-468-8 paperback $£ 14.95)$ is a series of meditations on ruins to explore their allure, their curiosity and the sense of fear that they arouse in those who contemplate the past through its physical traces. Proust figures highly, so in melancholy remembrance of things lost, 'The past is hidden somewhere outside the realm, beyond the reach of intellect, in some material object (in that sensation which that material object will give us) of which we have no inkling. And it depends on chance whether or not we come upon that object before we ourselves must die'.

ford, has resulted in a crop of fine books this quarter. Amongst these is GEORCE A. SAID-ZAMMIT's Population, land use and settlement on Punic Malta: a contextual analysis of the burial evidence. (BAR International series 682. xii+159 pages, 19 black \& white plates, 86 figures. 1997 . Oxford: Archaeopress; 0-86054-869-4 paperback $£ 30$ ). Split into three main sections, the first looks at the relationships between burial areas and settlement showing that agriculturally productive areas were settled and it is here that burials
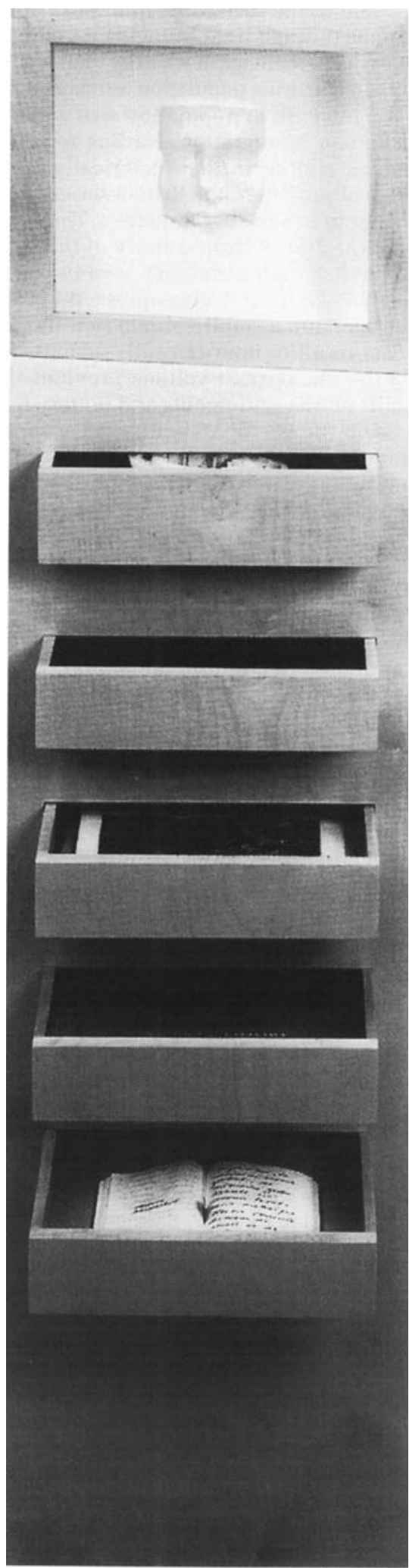
are to be found; the second section looks at wealth in the tombs through time, showing a trend to a reduction in the percentage of wealthy tombs; the third attempts to reconstruct population estimates, showing a dramatic increase in population size with the advent of Roman immigration, leading to a population number similar to that historically noted for the Medieval period. In the British series of BAR, a useful volume is STEPHEN BURROW's The Neolithic culture of the Isle of Man: a study of the sites and pottery. (BAR British series 263 . vi+149 pages, 117 figures. 1997. Oxford: Archaeopress; 0-86054-8724 paperback $£ 20$ ), a small volume rich in archaeological data, resulting from a recently submitted (1997) Ph.D thesis. The current volume provides the factual details on the settlements and pottery from excavations on the Isle of Man, divided according to early, middle and late Neolithic. An essential source for any future research on the Neolithic of this rich archaeological island. The interpretive parts of this thesis are to follow in future publications.

In The Roman domestic architecture of Northern Italy (BAR International series 670 . iv +144 pages, 62 figures. 1997. Oxford: Archaeopress; 0-86054-8619 paperback $£ 25$ ) by MiCHELE GEORGE is a study of the form of the town house, the domus, as oposed to the villa or multi-family insula, in what had been Gallia Cisalpina. GEORGE's study shows that as in southern Italy, the atrium had a limited period of popularity and was replaced by the peristyle in domestic houses. A catalogue at the end provides descriptions of the houses studies, plans and publication references. Finally, in a more anthropological vein there is MicHÈLE BIEWERS' L'habitat traditionnel à 'Aima: enquête ethnoarchéologique dans un village jordanien. (BAR International series 662. 163 pages, 116 figures, 13 tables. 1997. Oxford: Archaeopress; 0-86054-856-2 paperback £34). BIEwERs has produced a detailed ethnoarchaeological account of the small agricultural village of 'Aima in southern Jordan, with accounts of both land use and settlement construction. Separate chapters consider the developments in individual habitation as well as public space in the evolution of this village from 1953 to 1986.

MATHEW RESTALL's The Maya world: Yucatec culture and society 1550-1850. (xiv+441 pages, 8 figures, 5 maps, 39 tables. 1997. Stanford (CA): Stanford University Press; 0-8047-2745-7 hardback 245 \& \$55) is a social and cultural history of the Mayan peoples following the Spanish Conquest. Instead of following Spanish colonial accounts, Restall has based his work on notarial documents of the Yucatec Maya from archives in Mexico, the USA and Spain. Four parts consider identity and organization, society and culture, land and material culture, and literacy and language. What emerges is an account of the Maya cah, the selfgoverning municipality in which Mayans lived, that was far from disabled by colonial rule and in many important ways continued as before.
JENNIFER LAING's Art and society in Roman Britain ( ix +188 pages, 12 colour plates, 100 illustrations. 1997. Stroud: Sutton Publishing; 0-7509-0895-5 hardback $£ 19.99$ ) is a mixture between a book on Roman society and one on art, with chapters devoted to primarily one topic or the other.

\section{Fieldwork and surveys}

Compared to the sites of East Africa, the Lower Palaeolithic of northern Africa is poorly known, yet potentially vitally important. An important inroad into that disparity of information is to be found in MOHAMED SAHNOUNI's The Lower Palaeolithic of the Maghreb: evaluations and analyses at Ain Hanech, Algeria (Cambridge Monographs in African Archaeology 42. BAR International series 689, xiii+164 pages, 94 figures, 27 tables, \& appendices. 1997. Oxford: Archaeopress; 0-86054-875-9 paperback $£ 25$ ). This volume is a detailed presentation of recent excavation and artefactual work at the site of Ain Hanech, which has been dated, biostratigraphically and palaeomagnetically, to the period 1.9-1.8 million years ago. An important contribution to the archaeology of this period and area.

LINDA M. GREGONIS' The Hardy site at Fort Lowell Park, Tucson, Arizona (Arizona State Museum archaeological series $175 . x+75$ pages, 26 figures, 9 tables. 1997. Tucson (AZ): Arizona State Museum; 1-889747-66-1 paperback $\$ 14.95$ ) is an account of the University of Arizona's excavations (1976-78) of this large pre-Classic Hohokam village. The excavated depsoits date from the Snaketown to the Late Rincon sub-phases. Chapters deal with the excavation and the artefacts (ceramics and stone), whilst the discussion centres on the use of space at the site. The finds of various pine and ponderosa wood fragments indicate that the Hohokam inhabitants were exploiting a wider catchment than previously thought, perhaps supporting agriculture with foraged and hunted resources from higher elevations.

SVEND W. HELms. Excavations at Old Kandahar in Afghanistan 1976-1978: conducted on behalf of the Society for South Asian studies (Society for Afghan studies) stratigraphy, pottery and other finds. (Society for South Asian studies monograph 2. BAR International series 686 . xvi +397 pages, 16 black \& white plates, 231 figures, 11 tables. 1997. Oxford: Archaeopress; 0-86054-875-9 paperback $£ 25$.) The city of Old Kandahar has been throught to be the city of Alexandropoulis, eponymously founded by the Great conqueror in about 329/330 BC. Frequent excavations and constant redevelopment have left the city a ruin field. In this volume HELMS presents the 'raw archaeological data' from excavations conducted at the site between 1976 and 1978. Copious appendices provide lists of coins, inscriptions, figurines and pottery catalogues, whilst full illustrations for plans, sections and pottery are also provided.

The late Peter Gelling's excavations on Orkney have now been published in SIMON BuTEuX's Settlements 
$\Leftrightarrow$ Two sides to the life of Pan. In Edward Burne-Jones' luscious pre-Raphaelite painting, Pan's tender caress comforts Psyche in her search for Cupid; in Anton's cartoon, just the sight of Pan's leg is enough to suggest thoughts of unbridled passion. JOHN BOARDMAN'S The great God Pan: the survival of an image. (The Walter Neurath memorial lecture. 48 pages, 53 plates. 1998. London: Thames of

Hudson; 0-500-550301 hardback $£ 7.95$ ) is a brief essay on the career of Pan since the end of antiquity when Pan the Great God died. It is also a remarkable essay on the life of an image. In antiquity, Pan was a rural beast, primarily animal, slightly human, a figure of the country to be feared and worshipped, and ironically a loser in love. Since antiquity Pan has become a concept to be evoked in such ways that parts of his body represent characters of the human psyche or nature. Pan can be a teacher of nymphs, a natural spirit, a picture of ugly disfigured shame. He can also be a rural 'cupid', an exemplar of unfettered natural urges, and at the same time, like the beast in the fairytale, he is a figure to fear. He is the feared piper at the gates of Dawn in The Wind in the Willows, before whom Ratty and Mole must tremble.
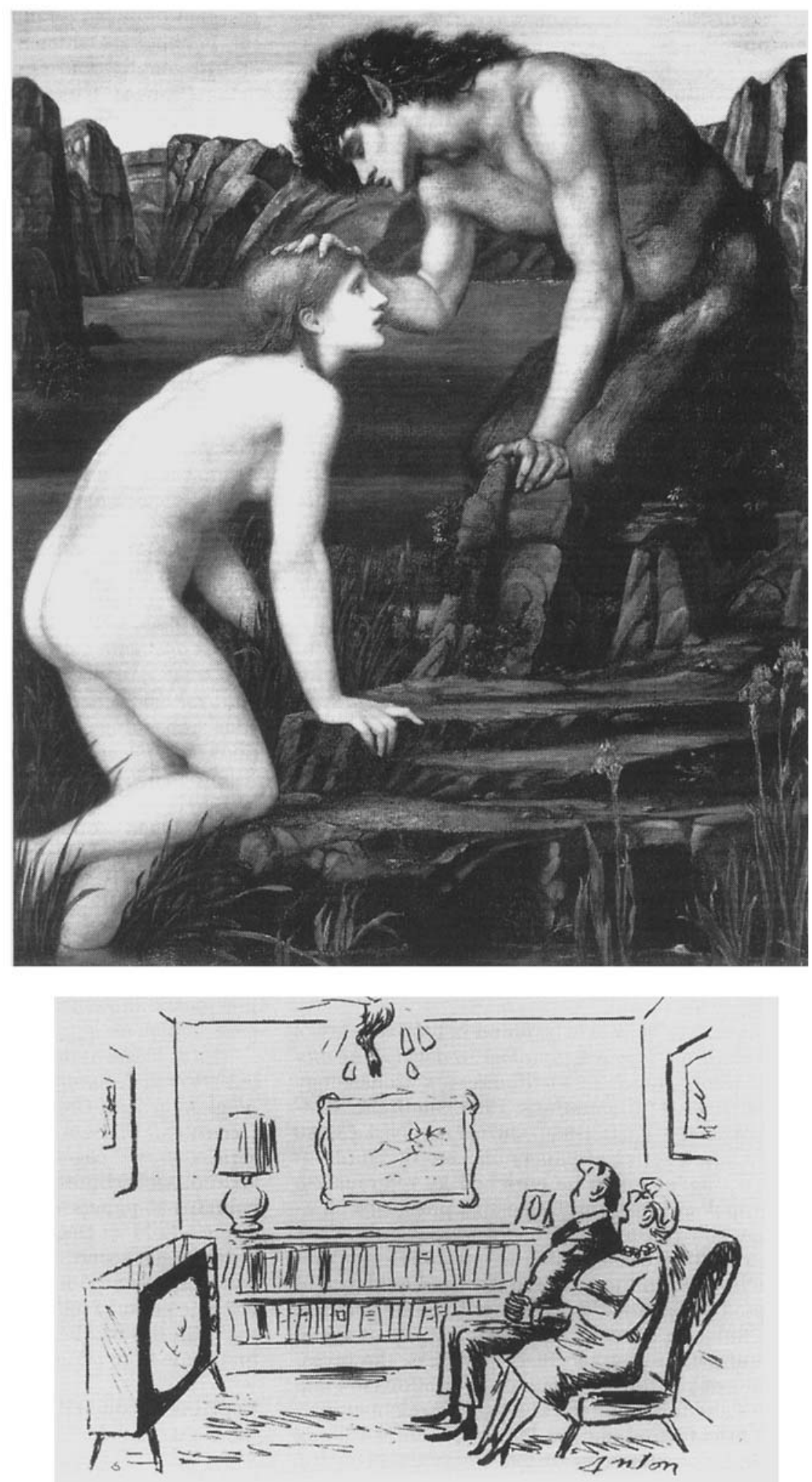

'Perhaps that will convince you that there's an orgy going on up there.' 
at Skaill, Deerness, Orkney: excavations by Peter Gelling of the Prehistoric Pictish, Viking and later periods. (BAR British series 260. vii+276 pages, numerous illustrations. 1997. Oxford: Archaeopress; 0-86054-865-3 paperback $£ 28$ ). The site itself provides evidence from the late Bronze Age, Iron AgePictish to the Norse periods. Detailed chapters by various authors deal with the evidence of the various periods, followed by specialist reports on the fnds, dating, etc.

ZARINE COOPER. Prehistory of the Chitrakot Falls, Central India (viii+115 pages, 27 plates. 1997. Pune: Ravish Publishers; 81-900294-1-x paperback Rs.685) is a study of 49 surface stations of lithic debris in this region of Central India. Analysis indicates that, contrary to earlier opinions, these locations do not represent factory sites but are the residues of subsistence activities related to the exploitation of riverine resources. Spatial analyses indicate that the lithic pieces are determined by large topographic features and erosional processes.

Finally ERIK HALLAGER \& BIRGITTA P. HALLAGER's (ed.) The Greek-Swedish excavations at the Agia Aikaterini Square Kastelli Khania 1970-1987 (Vol. I:1 text. 305 pages, 9 colour plates, 45 figures. 1997. Stockholm: Swedish Institute in Athens; 91-7916035-2 hardback. Vol I:2 plates. 141 pages all with plates. 1997. Stockholm: Swedish Institute in Athens; 91-7916-035-2 hardback) is the first of seven proposed volumes on this excavation of the excavations carried out between 1970 and 1987 in Agia Aikaterini Square in Khania in western Crete. $2 \cdot 5$ metres of deposit contain 5000 years of archaeology in more than 7000 stratified units, made all the more difficult by Late Minoan rubbish pits cut into the deposits and foundation trenches cut by the occupying Venetians right down to bedrock and the fill dispersed acorss the site.

\section{Conferences}

A provocative book is to be found in JUDITH LUSTIG's (ed.) Anthropology \& Egyptology: a developing dialogue (Monographs in Mediterranean archaeology 8. 147 pages, 41 illustrations. 1998. Sheffield: Sheffield Academic Press. 1-8507-5676-7 hardback £32.50 \& $\$ 53.50$ ), a series of papers on how the study of Ancient Egypt might be enriched by reference to anthropology (including linguistics, physical anthropology and cultural anthropology). Several papers illustrate the ways in which an anthropological approach, often to the traditionally used evidence of Egyptologists, provides a fresh, enlivening perspective. Subjects covered include the study of social differentiation from mortuary practices, the investigation of kinship, gender and age relations in tomb scenes and texts, and the analysis of setlement patterns from textual sources. Papers by senior authors looking from the more distanced perspective sug- gest that in the study of Egyptology a focus on cultural change provides a meeting ground on whch anthropologists and Egyptologists might come together. Robert Wenke is interested in the use of an evolutionary approach to considering change, Bruce Trigger reminds others that Egypt is similar in most respects ot other early civilizations, thus the generalizing approach of anthropologists is useful. An admittedly cynical essay by William Adams notes that the running in this rapprochement of the disciplines must come from Egyptologists: from his perspective as an anthropologist, he can see the study of anthropology getting along quite happily without reference to Ancient Egypt, but not the other way around.

KLAVS RANDSBORG's (ed.) Absolute chronologies: archaeological Europe 2500-500 BC (Acta Archaeologica vol. 67 (1996), Acta Archaeologica supplementa vol 1 (1996). 335 pages, numerous illustrations. 1996. Cobenhagen: Munksgaard; 0065-001X paperback DKK460) contains 26 papers presented at the conference on absolute chronologies in Verona in 1995. Papers are divided up according to dating technique; historical chronologies, relative chronologies, Carbon14 and dendrochronology, and within each section papers deal with dating in particular parts of Europe.

KATHRYN BERNICK 's (ed.). Hidden dimensions: the cultural significance of wetland archaeology (Pacific Rim archaeology. xvii+362 pages, several illustrations. 1997. Vancouver (BC): UBC Press; 0-7748-0632$\mathrm{X}$ hardback \$95; 0-7748-0633-8 paperback \$34.95) is a series of papers devoted to wetland archaeology, arranged around the themes of human adaptation to wetlands, set-site perspectives in the past and present, fishing technologies on the northwest coast and finally preservation and conservation in practice. Papers are roughly split half-way between those devoted to wet matters in the Americas and those in Europe, western and eastern. Much of the data is previously unpublished. Our copy has a number of pages left blank in printing, so check when ordering.

Not as recent as it might have been, JOHN BINTLIFF's (ed.) Recent developments in the history and archaeology of central Greece: proceedings of the 6 th in ternational Boetian conference (BAR International series 666. 377 pages, numerous illustrations. 1997. Oxford: Archaeopress; 0-86054-858-9 paperback £48) contains 25 papers and an introduction from a conference held in December 1989. Specialist papers are arranged according to chronological period with good representation from prehistory through the Archaic period, Hellenistic and Roman Greece ending with the medieval to Early Modern. Contributors come from all over Europe and North America.

\section{Reprints, second editions and paperbacks}

BRIAN M. FAGAN. Clash of cultures. (2nd edition.) 333 pages, numerous illustrations. 1998. London: 
Altamira Press; 0-7619-9146-8 paperback $£ 16.50$. An update of this book, first published in 1977, Fagan looks at a range of instances of the meeting of local small-scale societies and larger colonial nations, from the Aztecs and the Spanish, to the Japanese and the Americans. This is a sad tale of poor communications, myth-making and inequality.

JOHN S. HENDERSON. The world of the ancient Maya. (New edition.) xvii+329 pages, 11 colour plates, numerous black \& white plates \& illustrations, 9 maps. 1998. London: John Murray; 0-7195-5568-X hardback $£ 25$. This is a completely revised edition of his book, first published in 1981. Nine chapters lead the reader from the beginnings of the Maya civilization in the development of Mesoamerica, through its florescence to its later conquest by the Spanish. This second edition benefits not only from recent developments in the archaeology of the material record, but especially in the interpretation of Mayan inscriptions.

W.A. Cummins' The age of the Picts (ix +166 pages, 55 illustrations. 1998. Stroud: Sutton Publishing; 07509-1608-7£10.99) is a paperback imprint of his 1995 book, and comprises a series of introductory chapters leading into a chronological/geographic review of the archaeological and historical evidence for the Picts.

\section{Reference}

ARTHUR MACGREGOR's Ashmolean Museum Oxford: a summary catalogue of the continental archaeological colections (Roman Iron age, migration period, early Medieval) (BAR International series 674. iv +288 pages, numerous illustrations. 1997. Oxford: Archaeopress; 0-86054-863-5 paperback £55) is a catalogue of material largely collected by the late John Evans from all areas of Europe. Assessment of finds is largely based on visual details of the finds and each piece is accordingly illustrated photographically.

BRANKA MIGOTTI's Evidence for Christianity in Roman Southern Pannonia (Northern Croatia): a catalogue of finds and sites (BAR International series 684. v+117 pages, numerous ilustrations. 1997. Oxford: Archaeopress; 0-86054-870-8 paperback £30) is a detailed catalogue of materials used to illustrate an exhibition on the presence of Christianity in this region of Croatia. A brief discussion of the nature of Christianity in the Roman period leads to a consideration of the architectural/site evidence followed by a detailed catalogue of artefactual materials.

LESLEY \& ROY ADKINS' The handbook of British archaeology (319 pages, numerous illustrations. 1998. London: Constable; 0-09-478330-6 paperback £14.99) is the third edition of this work, first published in 1982. It remains a most useful work with information on all kinds of archaeological materials and sites, divided by period, from Palaeolithic to Medieval, followed by sections on archaeological techniques and that necessity of all classificatory schemes, miscellaneous.

ROBER'T A. SEGAL's (ed.) The myth and ritual theory (ix+473 pages, 3 figures. 1998. Oxford: Blackwell Publishers; 0-6312-0679-5 hardback $£ 50$ \& \$64.95; $0-6312-0680-9$ paperback $£ 15.99 \& \$ 29.95$ ) is a collected reader of articles concerning the interpretation of myth and ritual, more specifically the theory that the two are interconnected and cannot be interpreted without understanding how they affect one another. 29 collected articles chart the origin of this approach in the lectures of William Robertson Smith in biblical studies, through their development in the work of Frazer, and application to the ancient world, and worldwide, and on to their most recent revisions and evaluations by scholars such as Versnal in the early 1990s. A very complete anthology.

\section{Popular}

The cities of the ancient Andes (240 pages, 27 colour plates, 120 illustrations. 1998. London: Thames \& Hudson; 0-500-05086-4 hardback £17.95) by ADRIANA VON HAGEN \& CRAIG MORRIS is a straightforward introduction to the understanding of cities and urbanism in the Andes. Particular emphasis is placed on how the special topography and natural environment of the Andes affected the development of cities and their particular religious and economic role in Andean societies. As is usual with this publisher, this is a beautifully produced book with plenty of excellent photographs and architectural line drawings.

More a small notebook on facts and things about the Celtic World than an academic text is VicTor WALKLEY's Celtic daily life. (128 pages. 1997. London: Robinson; 1-85487993-6 hardback £6.99), gathered during the course of the author's busy life. Divided into a series of chapters; Celtic peoples, occupations and skills, everyday dress and 'high fashion' food, drink and herb lore, ritual and belief. A rather tasty recipe for Celtic Honey Cake is usefully included for foodies.

\section{Also}

Iznik ceramics from ancient Nicaea were the ceramics supplied to the court of the Ottoman empire, and from there to the mosques, palaces and other buildings. In Iznik pottery (128 pages, 43 colour plates, 52 black \& white plates, 1 map. 1998. London: British Museum Press; 0-7141-1482-0 paperback $£ 10.99$ ) JOHN CARSWELL examines the evolution of the ceramic designs and production techniques from the monochrome blue and white ceramics for Mehmed the Conqueror in his 15 th-century palace at Topkapi Saray, through a more painterly development, to their moment of perfection with the introduction of red and turquoise green to the palette. 